\title{
Review: Ekstraksi Pektin dari Limbah Kulit Kedondong (Spondias dulcis) dan Pemanfaatannya sebagai Edible Coating pada Buah
}

\author{
Clarissa, Grace Claudia, Michelle Tamara Putri, Chrisfella Cokro Handoyo, \\ Syahnazia Adinda Firdayanti, Milka, Warsono El Kiyat* \\ Departemen Teknologi Pangan dan Gizi, Fakultas Ilmu Hayati, Universitas Surya \\ * corresponding author : warsono.el.kiyat@gmail.com \\ DOI : 10.20885/ijca.vol2.iss1.art1
}

\section{ARTIKEL INFO}

Received : Desember 2018

Revised : Januari 2019

Published : Maret 2019

Kata kunci : ekstraksi, edible coating, kulit kedondong, pektin, buah, limbah

\begin{abstract}
ABSTRAK
Edible coating merupakan suatu lapisan tipis, terbuat dari bahan yang dapat dikonsumsi. Salah satu bahan baku edible coating yang alami adalah pektin. Kandungan pektin pada kulit buah kedondong cukup tinggi yaitu 9\% - 30\%, sehingga berpotensi untuk diolah menjadi bahan baku edible coating. Pektin merupakan senyawa polisakarida yang terdiri dari polimer galakturonan yang tersusun dari $\quad \alpha-(1 \rightarrow 4)-D$-asam galakturonat. Untuk mendapatkan karakteristik edible coating yang kuat, pektin harus memiliki derajat esterifikasi metil yang tinggi. Kajian bertujuan untuk menganalisis potensi ekstrak pektin dari limbah kulit buah kedondong sebagai bahan untuk pembuatan edible coating pada buah-buahan. Ekstraksi pektin dilakukan dengan cara mengeringkan kulit buah kedondong sehingga menjadi bubuk kulit kedondong, kemudian diekstraksi menggunakan asam sitrat. Coating dari kulit buah kedondong aman digunakan.
\end{abstract}

\section{PENDAHULUAN}

Buah merupakan salah satu jenis pangan yang umumnya memiliki kandungan nutrisi yang dibutuhkan oleh tubuh, seperti vitamin. Berdasarkan kandungan nutrisinya, buah dapat dibedakan menjadi bermacam-macam jenis, seperti buah yang kaya serat, tinggi kadar karbohidrat, dan lainnya [1]. Selain itu, buah pada umumnya juga memiliki kadar air yang tinggi. Tingginya kadar air dalam buah menyebabkan buah menjadi cepat rusak dan umur simpannya pendek karena kadar air yang tinggi tersebut memudahkan terjadinya pertumbuhan mikroorganisme pada buah [2].

Salah satu metode yang digunakan untuk memperpanjang umur simpan dari buah dan sayuran tanpa merusak kualitasnya yaitu dengan pengemasan menggunakan kemasan primer. Berbagai alternatif pembuatan pengemas primer guna memperpanjang umur simpan dari buah-buahan maupun sayuran telah banyak dikembangkan, termasuk penggunaan edible coating. Edible coating adalah suatu lapisan tipis, terbuat dari bahan yang dapat dikonsumsi, dan dapat berfungsi sebagai barrier agar tidak kehilangan kelembaban, bersifat permeabel terhadap gas-gas tertentu, serta mampu mengontrol migrasi komponen-komponen larut air yang dapat menyebabkan perubahan pigmen dan komposisi nutrisi sayuran dan buah [3].

Adapun salah satu senyawa yang dapat digunakan sebagai bahan baku pembuatan alternatif plastik ramah lingkungan yang termasuk edible coating adalah pektin. Penggunaan pektin sebagai bahan baku pembuatan edible coating karena pektin merupakan salah satu turunan dari polisakarida yang memiliki fungsi sebagai membran permeable selektif terhadap pertukaran gas $\mathrm{CO}_{2}$ dan $\mathrm{O}_{2}$ [4]. Oleh sebab itu, penggunaannya dapat memperpanjang umur simpan karena respirasi buah dan sayuran menjadi berkurang [3]. 
Kulit kedondong yang selama ini menjadi limbah dari hasil konsumsi buah kedondong memiliki kandungan pektin yang cukup tinggi yaitu 9\% - 30\% [5]. Pada buah kedondong utuh, terdapat sekitar 19\% bagian kulitnya, yang merupakan bagian utama yang tidak dikonsumsi dari keseluruhan buah kedondong [6]. Hal ini menjadi potensi bagi kulit kedondong untuk dimanfaatkan. Pemanfaatan limbah kulit komoditas pertanian (petai) memberikan dampak positif bagi berbagai aspek, seperti ekonomi, sosial, lingkungan dan kesehatan [7]. Sejauh ini, bagian dari tanaman kedondong yang telah banyak dikaji potensinya yaitu pada kulit batang sebagai sumber flavonoid [8] yang berkhasiat sebagai antioksidan, antikanker, antibakteri, dan antiinflamasi [9], pada daun kedondong sebagai sumber antifungi [10], sari buah kedondong sebagai sumber antioksidan [11], dan kulit buah kedondong sebagai bahan dasar sirup glukosa [12]. Pemanfaatan kulit kedondong cukup potensial untuk diolah, salah satunya sebagai sumber pektin [5] untuk bahan baku pembuatan edible coating yang ramah lingkungan [13], [14]. Selain itu, penggunaan kulit kedondong sebagai sumber pektin dalam pembuatan edible coating dapat menjadi salah satu sarana pemberdayaan pangan lokal berupa buah kedondong yang saat ini masih sedikit pemanfaatannya. Kajian ini dilakukan untuk menganalisis potensi ekstrak pektin dari limbah kulit buah kedondong sebagai bahan untuk pembuatan edible coating pada buah-buahan.

\section{KEDONDONG}

Kedondong (Spondias cytherea Sonn.) adalah buah yang termasuk ke dalam keluarga Anacardiaceae. Pohon kedondong dapat banyak ditemukan di daerah tropis seperti Asia Selatan dan Asia Tenggara [15]. Pohon kedondong memiliki batang berkayu keras, kuat, tumbuh secara tegak, percabangan batang simpodial, permukaan batang yang halus dan berwarna putih kehijauan. Dalam pertumbuhannya tanaman kedondong membutuhkan banyak cahaya dan curah hujan 1000$1500 \mathrm{~mm} /$ tahun dengan suhu sekitar $30^{\circ} \mathrm{C}$ dan kelembaban udara sekitar $14 \%$. Walaupun pertumbuhannya optimal pada suhu hangat, tanaman kedondong mampu bertahan hidup pada suhu rendah $-3,9^{\circ} \mathrm{C}$ sekalipun. Tanaman kedondong dapat tumbuh hingga ketinggian 12-18 meter dengan keadaan tanah subur dan dengan keadaan tanah yang tidak terlalu tinggi kondisi $\mathrm{pH}$ nya [16]. Tanaman ini terbilang mudah untuk tumbuh diberbagai jenis tanah, dari tanah berbatu hingga tanah berpasir [17]. Banyak bagian dari tanaman kedondong yang memiliki kegunaan bagi kesehatan jika dikonsumsi. Daun dari kedondong dapat digunakan sebagai pereda batuk, pembengkakan mata, diare, dan penyakit kelamin. Buah kedondong yang belum matang memiliki kemampuan untuk meredakan reumatik dan radang tenggorokan. Pada ekstrkasi pektin, kulit buahbuahan sitrus dan apel sering dijadikan sebagai sumber produksi pektin komersil. Penggunaan kulit kedondong dapat dijadikan sebagai alternatif sumber pektin.

\section{PEKTIN}

Pektin komersil biasa digunakan sebagai bahan tambahan pangan. Pektin komersil ini bisa mengandung setidaknya $65 \%$ asam galakturonat dengan tambahan gula dan sodium atau garam buffer kalsium. Dewasa ini pektin komesil biasa diambil dari kulit sitrus sebagai sumbernya. Pektin memiliki tingkat degradasi yang tinggi. Pektin dapat dengan mudahnya terdegradasi dengan enzim maupun pada proses pemanasan [18]. Pektin merupakan senyawa polisakarida yang terdiri dari polimer galakturonan yang tersusun dari $\alpha(1 \rightarrow 4)$ D-asam gakaturonat (Gambar 1). Susunan poligalakturonat ini dapat teresterifikasi menjadi metilester dan gugus asam bebas. Rasio galakturonat yang teresterifikasi dengan total senyawa galakturonat disebut sebagai derajat esterifikasi (DE). Derajat esterifikasi tertinggi dapat diperoleh dengan ekstraksi dari bahan mentah alami. Pektin diklasifikasikan berdasarkan derajat esterifikasinya. Tingkat methoxylation digunakan untuk untuk mengklasifikasikan pektin tinggi metoksil $(\mathrm{DM}>50)$ dan pektin rendah metoksil $(\mathrm{DM}<50)$. Pektin tinggi metoksil biasa digunakan dalam indsutri selai, jeli, jus/sari buah, buah kalengan, susu dan gula-gula, sedangkan pektin rendah metoksil tidak terlalu dipengaruhi oleh $\mathrm{pH}$ dan dapat digunakan dengan rentang $\mathrm{pH}$ yang cukup besar [19]. 
Sifat penting pektin adalah kemampuannya dalam membentuk gel. Gel terbentuk saat pektin berikatan dengan air. Sebelum terbentuknya gel senyawa pektin tunggal akan dikelilingi oleh molekul-molekul air. Apabila lingkungan dari molekul pektin tersebut merupakan larutan yang asam, makan pektin akan kehilangan daya ikat airnya dan akan dapat berikatan menjadi satu membentuk gel. Pembentukan gel dikarenakan adanya ikatan silang oleh ikatan hidrogen, dan adanya jembatan kalsium [19]. Pada pembentukan gel, ada beberapa parameter yang harus diperhatikan, yaitu suhu, $\mathrm{pH}$, dan pelarut yang digunakan, serta ion kalsium. Efek suhu yang terlalu tinggi akan mengakibatkan pembentukan gel yang terlalu cair, sedangkan pada suhu yang lebih rendah gel akan terbentuk. Sebelumnya telah dijelaskan bahwa terdapat dua penggolongan jenis pektin, yaitu pektin tinggi metoksil dan pektin rendah metoksil. Kedua jenis pektin tersebut memiliki mekanisme pembentukan gel yang berbeda [19]. Pembentukan pektin tinggi metoksil membutuhkan suhu yang tinggi, $\mathrm{pH}$ yang rendah, dan pelarut yang digunakan harus lebih tinggi. Nilai $\mathrm{pH}$ yang digunakan pada umumnya lebih kecil daripada 3,8 dan pelarut yang digunakan minimal sebesar $55 \%$.
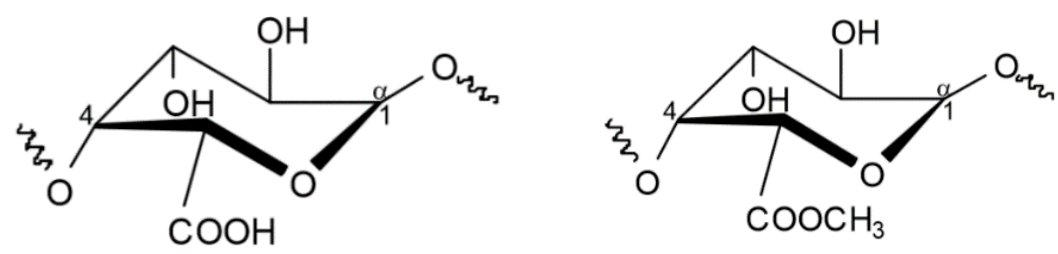

Gambar 1. Asam galakturonat (kiri) dan methyl esterified galakturonat [19]

\section{EDIBLE COATING}

Edible coating dapat didefinisikan sebagai pengemas primer dari sebuah produk yang terbuat dari komponen yang edible atau dapat dimakan. Edible coating adalah salah satu bentuk strategi perpanjangan umur simpan pada buah dan sayur-sayuran. Edible coating bersifat ramah lingkungan, terutama edible coating yang memang terbuat dari bahan alami [20]. Adanya edible coating pada suatu buah atau sayuran dapat mengatur pertukaran gas, properti mekanis, sensoris, kepraktian, serta perlindungan mikrobiologis. Edible coating biasa berada dalam bentuk cairan yang kemudian dilumurkan secara merata di produk [21]. Edible coating dapat terbuat dari berbagai macam bahan yang berbeda, tergantung dengan karakteristik akhir produk yang diinginkan. Bahan utama yang biasa digunakan dalam pembuatan edible coating meliputi polisakarida, protein, dan senyawa lipid.

Coating polisakarida memiliki sifat dasar hidrofilik, dimana sifat ini dapat memberikan kemampuan ketahanan terhadap kelembaban yang sangat kecil. Meskipun begitu pengaturan pertukaran gas tetap berfungsi dengan baik dan dapat memperpanjang umur simpan buah tanpa harus membuat kondisi anaerobik yang berlebihan. Salah satu jenis coating polisakarida yang sering digunakan pada produk buah-buahan adalah alginat dan karagenan. Aplikasi coating alginat dan karagenan ini dapat berpengauh terhadap beberapa parameter meliputi kehilangan berat, $\mathrm{pH}$, total padatan terlarut, warna, dan kepadatan. Coating alginat memiliki kekuatan tarikan yang lebih baik dan permeabilitas terhadap uap air yang lebih rendah jika dibandingkan dengan coating karagenan. Hal ini akan memberikan hasil yang lebih baik pada ketahanan produk [22]. Contoh lain coating polisakarida adalah pektin. Edible coating dari pektin ini memiliki ketahanan air yang rendah, sehingga coating ini lebih baik diaplikasikan pada produk dengan kadar air yang rendah [23].

Coating dari protein biasa diambil dari jagung, gandum, kacang-kacangan, susu, atau gelatin. Coating ini memiliki kemampuan pertahanan akan karbon dioksida dan oksigen yang baik. Bahan 
utama yang biasa digunakan dalam pembuatan protein edible coating meliputi gluten, kolagen, zein, kasein, dan whey protein [24]. Sebuah penelitian menyatakan bahwa kalsium kaseinat dan whey protein coating dapat memperlambat proses pencoklatan pada potongan apel dan kentang secara signifikan. Coating lipid dapat terbuat dari wax, acylglycerol, atau asam lemak. Coating lipid sangat efisien dalam mencegah perpindahan uap air dari produk. Sifat hidrofobik dari senyawa lipid membantu mencegah adanya penurunan berat produk akibat dehidrasi. Wax alami seperti carnauba wax, dan beeswax sering digunakan sebagai edible coating pada [20].

\section{POTENSI PEKTIN SEBAGAI SUMBER EDIBLE COATING}

Sebanyak 19\% dari total berat buah kedondong adalah kulitnya, yang merupakan bahan mentah utama untuk diolah menjadi pektin [5]. Pektin harus stabil dalam kondisi asam (asam lambung saat dicerna). Kandungan dalam kulit kedondong menentukan karakteristik biokimia pektin yang terbentuk. Pektin hasil ekstraksi kulit kedondong mengandung asam uronat (uronic acid) sebanyak $557-727 \mathrm{mg} / \mathrm{g}$ berat kering, total gula mencapai $125-158 \mathrm{mg} / \mathrm{g}$ berat kering, dan derajat metilasi $50-$ $58 \%$ [5]. Rendemen tertinggi diperoleh pektin yang diekstraksi dengan asam oksalat atau amonium oksalat dengan massa molardan derajat metilasi yang tinggi. Hal ini menunjukkan bahwa adanya potensi perolehan pektin dari kulit buah kedondong.

Untuk memperoleh karakteristik yang kuat agar dapat dijadikan sebagai bahan edible coating, maka pektin harus memiliki degree of methyl-esterification (DM) tinggi. Derajat metil esterifikasi yang tinggi dapat diperoleh melalui jangka waktu ekstraksi yang singkat pada suhu yang mendekati suhu didih. Hal ini berfungsi untuk mereduksi de-esterifikasi sehingga ikatan silang yang terbentuk menjadi lebih kuat [25]. Perolehan pektin melalui ekstraksi biasanya dilakukan dengan memberikan asam mineral pada bahan mentah dengan suhu yang tinggi. Asam yang digunakan biasanya adalah asam nitrat. Melalui proses ini, maka pektin yang diperoleh telah tinggi metoksilasi (DM lebih besar dari 50\%) dan sedikit asetilasi [5].

Pektin dibagi menjadi dua berdasarkan gelasi pektin, yaitu Low Methoxy Pectin (LMP) dan High Methoxy Pectin (HMP). Kedua jenis pektin ini memberikan karakteristik yang berbeda. Apabila terdapat gula dan asam, maka HMP sangat mudah untuk membentuk gel. Mekanisme gelasi pada pektin tergantung pada DE yang dimiliki [26]. DE menunjukkan persentase gugus karbonil yang diesterifikasikan dengan metanol. Apabila gugus karboksil yang dimetilasi lebih dari $50 \%$, maka pektin yang dihasilkan tergolong dalam HMP, sedangkan apabila kurang dari 50\% maka tergolong LMP. Keduanya memiliki perbedaan yang tertera jelas pada kemampuan membentuk gel.

LMP sangat sensitif terhadap kehadiran ion divalen, contohnya kalsium. Adanya ion kalsium mampu membentuk ikatan intermolekuler antara gugus homogalakturonat yang menyebabkan pektin membentuk gel [27]. Struktur yang dibentuk dari ikatan tersebut seperti egg-box, dimana struktur ini terbentuk karena adanya interaksi elektrostatis [26]. Sifat viskoelastis dari pektin inilah yang sering dimanfaatkan oleh industri pangan sebagai agen pengental dan penstabil [28].

Berbeda dengan LMP yang membentuk gel dengan keberadaan ion divalen, HMP akan membentuk gel apabila terdapat konsentrasi fruktosa atau sukrosa yang tinggi dan $\mathrm{pH}$ yang rendah [28]. Kemampuan HMP dipengaruhi oleh DE, yaitu nilai DE yang semakin besar menunjukkan bahwa kemampuan pektin menjadi gel akan semakin kuat [29]. Teknologi yang lebih efisien untuk memperoleh LMP sudah berkembang, yaitu menggunakan deesterifikasi enzim [30].

Pada penelitian yang dilakukan oleh Tiwari et al., maka perhitungan DE dilakukan untuk menentukan sifat HMP dan LMP [31]. Perhitungan DE akan dilakukan dengan menggunakan metode titrimetri. Pektin kering ditambahkan etanol dan dilarutkan menggunakan air suling. Indikator phenophtalein digunakan sebagai indikator warna dalam metode titrimetri ini. Tiga tetes indikator ditambahkan dalam sampel dan kemudian dititrasi oleh $\mathrm{NaOH} 0,1 \mathrm{~N}$. Titik akhir titrasi 
dinyatakan dengan perubahan warna menjadi merah muda. Berdasarkan hal ini maka didapatkan jumlah gugus karboksil bebas dari jumlah volume $\mathrm{NaOH} 0,1 \mathrm{~N}$ yang terpakai hingga mencapai titik

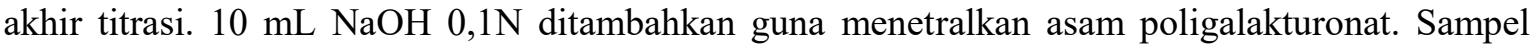
tersebut kemudian ditutup dengan penutup dan dikocok dengan kuat. Kemudian, larutan ini didiamkan dalam suhu ruang untuk deesterifikasi pektin. Asam hidroklorat $0,1 \mathrm{~N}$ kemudian ditambahkan sebanyak $10 \mathrm{~mL}$ ke dalam sampel untuk menetralkan $\mathrm{NaOH}$. Sampel tersebut dikocok hingga warna merah muda hilang. Selanjutnya dilakukan titrasi kembali menggunakan $\mathrm{NaOH} 0,1 \mathrm{~N}$ hingga warna merah mudah kembali terbentuk. Berdasarkan titrasi tersebut, maka didapatkan jumlah gugus karboksil yang teresterifikasi. Jumlah gugus karboksil teresterifikasi inilah yang disebut DE. Rumus perhitungan DE disajikan pada Persamaan 1 [32].

$$
D E(\%)=\frac{\text { Volume akhir titrasi }(m L)}{\text { Volume awal titrasi }(m L)+\operatorname{VoLume~akhir~titrasi~}(m L)}
$$

\section{PEMBUATAN HIGH METOXY PECTIN (HMP)}

Pembuatan pektin HMP mengandung empat tahapan, yaitu tahap persiapan, ekstraksi, purifikasi, dan konsentrasi dan presipitasi. Kulit buah yang sudah dikupas direndam dalam air untuk membuang bahan-bahan yang tidak diperlukan, namun larut dalam air. Selanjutnya ekstraksi dimulai dengan melarutkan kulit buah yang sudah direndam dengan air panas $80^{\circ} \mathrm{C}$ Pelarutan kulit buah dalam air panas tersebut menghasilkan larutan pektin. Selanjutnya, dilakukan purifikasi untuk mengadsorpsi komponen fenolik yang masih terdapat dalam kulit buah. Tahap terakhir adalah kulit buah yang sudah melalui berbagai proses diuapkan pada tray atau menggunakan hot plate. Sebelum mendapatkan HMP maka kulit buah yang sudah diuapkan akan dipresipitasi menggunakan alkohol [33].

\section{EKSTRAKSI PEKTIN}

Ekstraksi pektin dari kulit buah kedondong akan menghasilkan pektin dan minyak atsiri dari kulit buah kedondong. Kulit buah kedondong harus dikeringkan terlebih dahulu menggunakan panas matahari hingga kering dan dapat dihancurkan menjadi bubuk kulit kedondong. Untuk mendapatkan minyak atsiri kulit kedondong maka ekstraksi dilakukan dengan pelarut organik seperti petroleum eter menggunakan distilasi sederhana. Kulit kedondong bubuk yang telah diperoleh sebelumnya akan diekstraksi menggunakan asam [31]. Asam mineral kuat paling sering digunakan pada ekstraksi. Penggunaan asam mineral kuat bersifat aman, tidak menimbulkan efek korosif, dan tidak membahayakan lingkungan [34]. Asam yang digunakan juga bermacam-macam, seperti amonium oksalat, asam sulfat, asam sitrat, natrium sitrat, dan asam klorida. Namun asam yang paling sering digunakan adalah asam sitrat [14].

Asam sitrat dengan $\mathrm{pH}$ 1-3 digunakan untuk mengekstraksi pektin. Kulit buah kedondong yang telah dikeringkan diekstraksi menggunakan asam sitrat sambil dipanaskan dengan suhu $65^{\circ} \mathrm{C}$ dan diaduk selama 30 menit. Setelah itu, maka larutan ditunggu dingin dan filtrasi menggunakan bantuan kain saring. Filtrat yang didapatkan akan dicuci menggunakan alkohol sebanyak dua kali. Hasil yang didapatkan adalah pektin yang berbentuk gel dan mengendap. Pektin tersebut diuapkan dalam oven uap panas dengan suhu $40^{\circ} \mathrm{C}$ selama 20 menit [31].

\section{EDIBLE COATING BERBAHAN DASAR PEKTIN}

Metode coating dapat dilakukan dengan tiga cara, seperti dengan teknik menyelupan (dipping), penyemprotan (spraying), dan penyikatan (brushing) [35]. Pembuatan edible coating yang mengandung pektin dapat dilakukan dengan membuat larutan yang mengandung pektin terlebih 
dahulu. Bubuk pektin dilarutkan dalam akuades. Kemudian larutan ini dicampur dengan polietilen glikol (PEG) dan dihomogenkan selama satu jam. Selanjutnya larutan disonikasi selama satu jam untuk menghilangkan gelembung udara [36].

Aplikasi edible coating banyak digunakan untuk buah-buahan dan sayur-sayuran yang memiliki sifat mudah rusak. Pada teknik celup (dipping), maka produk yang segar dicelupkan dalam larutan pektin, kemudian diuapkan terlebih dahulu. Setelah diuapkan, maka buah segar sudah diterlapisi dengan baik. Perbedaannya dengan teknik semprot dan sikat, maka pada teknik semprot digunakan apabila larutan pektin bersifat tidak terlalu kental sehingga dapat disemprotkan. Beberapa hal perlu diperhatikan untuk teknik semprot, seperti temperatur mulut alat semprot yang digunakan, ketebalan alat semprot, kecepatan aliran udara dan air, kelembaban udara larutan pektin, suhu dan lama pengeringan [35]. Pada teknik sikat, maka di dalam mesin akan terdapat sikat yang sudah terlumuri oleh larutan pektin yang akan melapisi produk [35].

Umumnya, dari ketiga cara coating maka yang paling sering digunakan adalah teknik celup. Teknik ini digunakan apabila larutan pektin bersifat kental. Produk akan dicelupkan pada larutan pektin selama 5-30 detik. Coating yang berperan sebagai pelapis pada buah dan sayuran dapat berfungsi sebagai membran semi permiabel yang menghambat kecepatan pertukaran gas dan menciptakan material baru sebagai penyalut yang akan meningkatkan umur simpan [14].

Isolasi pektin dilakukan dengan mengupas kulit buah kedondong, diiris tipis-tipis dan dibersihkan dari segala kotoran yang masih menempel. Kulit buah ini dihaluskan dan kemudian ditambahkan alkohol 96\% dengan perbandingan buah dan alkohol 1:2. Setelah menjadi bubur kulit kedondong, maka selanjutnya didiamkan selama kurang lebih 30 menit. Kemudian, sampel kulit kedondong ditambahkan larutan $\mathrm{HCl}$ untuk membentuk suasana asam. Selanjutnya, bubur kulit kedondong dipanaskan dengan suhu $7^{\circ} \mathrm{C}$ selama 120 menit. Hasilnya akan disaring dan filtrat dipanaskan pada suhu $90^{\circ} \mathrm{C}$ hingga mencapai setengah kali volume semula. Filtrat yang sudah dingin ditambahkan alkohol dan $\mathrm{HCl}$ pekat, lalu didiamkan selama 10-14 jam. Endapan yang terbentuk akan dikeringkan hingga mencapai suhu ruang. Larutan edible coating dibuat dengan melarutkan tepung pektin dalam aquades. Setelah dicampurkan maka larutan ditambahkan gliserol dan dipanaskan pada suhu $40^{\circ} \mathrm{C}$. Larutan didinginkan dan ditambahkan larutakn $\mathrm{NaHCO}_{3}$ dan $\mathrm{CaCl}_{2}$ 0,5\%.

\section{APLIKASI EDIBLE COATING BERBASIS PEKTIN PADA PRODUK PANGAN}

Edible coating berbasis pektin dapat diaplikasikan pada produk pangan seperti tomat [37], mangga [38], dan keripik pisang [39] yang disajikan pada Tabel 1. Secara umum, fungsi dari edible coating yaitu untuk mempertahankan umur simpan dan kualitas dari produk pangan yang diaplikasikan. Akan tetapi, karena karakteristik dari setiap produk pangan berbeda-beda, sehingga proses aplikasi serta tujuan spesifik dari penggunaan edible coating berbasis pektin cukup bervariasi. Konsentrasi pektin yang digunakan untuk mendapatkan kualitas edible coating yang baik dari masing-masing produk pangan tidak jauh berbeda. Hal ini juga bergantung pada ukuran produk pangan serta metode aplikasinya.

\subsection{Tomat}

Pada penyalutan buah tomat, digunakan larutan pektin 3\%. Konsentrasi larutan pektin yang semakin tinggi dapat memberikan ketebalan dan kepekatan lapisan yang semakin tinggi. Hal ini berdampak pada buah tomat, yaitu pori-pori buah semakin tertutup sehingga proses respirasi dan transpirasi dapat ditekan. Pencelupan buah tomat dalam larutan pektin dilakukan selama dua kali. Buah tomat tersebut dicelup selama 5 menit, kemudian ditiriskan. Penyimpanan buah tomat yang telah disalut disimpan pada suhu $4^{\circ} \mathrm{C}$. Pelapisan buah tomat dapat menurunkan total asam buah tomat selama penyimpanan berlangsung. Coating yang didapatkan dari larutan pektin alami lebih baik daripada coating plastik. Coating menurunkan susut bobot pada buah-buahan [37]. 


\subsection{Mangga}

Mangga merupakan buah klimakterik sehingga respirasinya semakin cepat saat pematangan. Buah ini masak dengan cepat sekitar 3 sampai 9 hari setelah dipanen sehingga harus dikonsumsi segera. Oleh sebab itu, edible coating pada mangga diperlukan untuk mempertahankan mutu buah dalam waktu yang lebih lama. Berdasarkan penelitian yang dilakukan, coating berbasis pektin yang diterapkan pada mangga bekerja efektif menghambat perubahan karakteristik fisik dan memperpanjang umur simpan. Coating mampu memberikan daya tarik visual mangga karena memberikan efek mengkilau. Selain itu coating mampu mengurangi kerusakan fisik, perubahan warna pada kulit dan daging serta meminimalkan pelunakan jaringan. Pektin dapat digunakan bersamaan dengan bahan lain untuk memberikan pelapisan yang maksimal. Edible coating terbaik merupakan campuran pektin dengan $28 \%$ sorbitol dan $23 \%$ beeswax [38].

\subsection{Keripik Pisang}

Edible coating berbasis pektin juga dimanfaatkan untuk melapisi produk keripik pisang untuk menghalangi terjadinya absorbsi minyak pada produk pangan yang digoreng, sehingga memperbaiki kualitas gizi produk pangan. Penelitian Ulfah menggunakan edible coating berbasis pektin sebanyak $2 \%$ dengan cara merendam irisan pisang selama 1 menit kedalam larutan pektin. Irisan pisang yang telah direndam kemudian digoreng pada suhu $180^{\circ} \mathrm{C}$ selama 9 menit. Penelitian ini menunjukkan efektifitas penggunaan pektin dalam edible coating dengan penurunan kadar akrilamida dapat mencapai 90\%. Edible coating juga tidak mempengaruhi karakteristik fisik pada pisang dan tidak mempengaruhi tingkat kesukaan konsumen terhadap tekstur dan rasa keripik pisang [39].

TABEL I. Aplikasi edible coating berbasis pektin pada beberapa produk pangan

\begin{tabular}{|c|c|c|c|c|}
\hline $\begin{array}{l}\text { Produk } \\
\text { Pangan }\end{array}$ & $\begin{array}{l}\text { Penambahan } \\
\text { Pektin }\end{array}$ & Proses & $\begin{array}{l}\text { Karakteristik dan Fungsi Edible } \\
\text { Coating }\end{array}$ & Referensi \\
\hline $\begin{array}{l}\text { Buah } \\
\text { Tomat }\end{array}$ & $3 \%$ & $\begin{array}{l}\text { - Pencelupan } \\
\text { dilakukan } 2 \text { kali } \\
\text { selama } 5 \text { menit } \\
\text { - Penyimpanan } \\
\text { pada suhu } 4^{\circ} \mathrm{C}\end{array}$ & $\begin{array}{l}\text { - Menghambat respirasi dan } \\
\text { transpirasi } \\
\text { - Menurunkan total asam } \\
\text { - Menurunkan susut bobot }\end{array}$ & [37] \\
\hline Mangga & $3,3 \%$ & $\begin{array}{l}\text { - Pencelupan dapat } \\
\text { dilakukan dengan } \\
\text { menambahkan } \\
\text { sorbitol } 28 \% \text { dan } \\
\text { beeswax } 23 \%\end{array}$ & $\begin{array}{l}\text { - Mempertahankan mutu buah } \\
\text { - Memperpanjang umur simpan } \\
\text { - Menghambat perubahan fisik } \\
\text { - Memberikan efek mengkilau }\end{array}$ & [38] \\
\hline $\begin{array}{l}\text { Keripik } \\
\text { Pisang }\end{array}$ & $2 \%$ & $\begin{array}{l}\text { - Perendaman } \\
\text { pisang yang diiris } \\
\text { selama } 1 \text { menit }\end{array}$ & $\begin{array}{l}\text { - Menghambat absorbsi minyak } \\
\text { - Memperbaiki kualitas gizi } \\
\text { - Menurunkan akrilamida } \\
\text { hingga } 90 \% \text { mempengaruhi } \\
\text { - Tidak } \\
\text { karakteristik fisik dan sensori } \\
\text { pisang }\end{array}$ & [39] \\
\hline
\end{tabular}

\section{KESIMPULAN}

Kulit buah kedondong dapat menghasilkan rendemen pektin yang tinggi sehingga berpotensi untuk dimanfaatkan sebagai bahan pembuatan edible coating. Edible coating berbahan dasar pektin secara luas digunakan untuk berbagai produk pangan. Penggunaan pektin dari limbah kulit kedondong dapat dikembangkan karena penggunaannya aman dan ramah lingkungan 
(biodegradable). Edible coating yang dihasilkan dari limbah kulit buah kedondong dapat bermanfaat untuk memperpanjang umur simpan pada buah-buahan dan menjaga kualitas produk. Metode ekstraksi pektin dan penggunaannya sebagai edible coating terdapat berbagai macam cara berdasarkan jenis buah-buahan yang akan digunakan.

\section{Ucapan Terima Kasih}

Penulis mengucapkan terima kasih kepada Lembaga Penelitian dan Pengabdian Masyarakat (LPPM) Universitas Surya atas bimbingan dan konsultasinya selama penyusunan naskah.

\section{Daftar Pustaka}

[1] A. Rakhmawati, "Mikrooganisme Kontaminan pada Buah,” Tegalrejo, 2013.

[2] H. F. Habibie, "Pengaruh Edible Coating Berbasis Pektin dengan Penambahan Minyak Atsiri Sereh Dapur (Cymbopogon citratur) terhadap Kualitas Pepaya MJ9," Universitas Sebelas Maret, 2016.

[3] E. A. Baldwin, R. Hagenmaier, and J. Bai, Edible Coatings and Films to Improve Food Qualit, 2nd ed. Boca Raton: CRC Press, 2016.

[4] M. Miskiyah, W. Widaningrum, and C. Winarti, "Aplikasi Edible Coating Berbasis Pati Sagu dengan Penambahan Vitamin C pada Paprika: Preferensi Konsumen dan Mutu Mikrobiologi," J. Hortik., vol. 21, no. 1, pp. 68-76, 2011.

[5] B. B. Koubala, L. I. Mbome, G. Kansci, F. T. Mbiapo, and M. Crepeau, "Physicochemical properties of pectins from ambarella peels ( Spondias cytherea ) obtained using different extraction conditions," Food Chem., vol. 106, no. 3, pp. 1202-1207, 2008.

[6] C. D. May, "Industrial Pectins: Sources, Production and Applications," Carbohydr. Polym., vol. 12, pp. 79-99, 1990.

[7] A. Rianti, E. K. Parassih, A. E. Novenia, A. Christpoher, D. Lestari, and W. El Kiyat, "Potensi Ekstrak Kulit Petai (Parkia speciosa) sebagai Sumber Antioksidan," J. Dunia Gizi, vol. 1, no. 1, pp. 10-19, 2018.

[8] S. Salmia, "Analisis Kadar Flavonoid Total Ekstrak Kulit Batang Kedondong Bangkok (Sapondias dulcis) dengan Metode Spektrofotometri UV-VIS," Universitas Islam Negeri Alauddin Makassar, 2016.

[9] I. P. Suparman, I. Sudira, and I. Berata, "Kajian Ekstrak Daun Kedondong (Spondias dulcis) Diberikan Secara Oral pada Tikus Putih ditinjau dari," Hispatologi Ginjal, vol. 5, no. 1, pp. 49-59, 2013.

[10] S. Fitriani, R. Raharjo, and G. Trimulyono, "Aktivitas Antifungi Ekstrak Daun Kedondong (Spondias pinnata) dalam Menghambat Pertumbuhan Aspergillus flavus," Lentera Bio, vol. 2, no. 2, pp. 125-129, 2013.

[11] R. Rakhmawati and Y. Yunianta, "Pengaruh Proporsi Buah: Air dan Lama Pemanasan terhadap Aktivitas Antioksidan Sari Buah Kedondong (Spondias dulcis)," J. Pangan dan Agroindustri, vol. 3, no. 4, pp. 1682-1693, 2015.

[12] D. Putri, "Pemanfaatan Sirup Glukosa Hasil Hidrolisa Selulosa dari Kulit Buah Kedondong (Spondias dulcis Forst) yang Dimanfaatkan sebagai Pemanis pada Pembuatan Manisan dari Buah (Naphelium Longanum) Lengkeng," Universitas Sumatera Utara, 2012.

[13] D. Suput, V. L. Lazic, S. Z. Popovic, and N. M. Hromis, "Edible films and coatings: Sources, properties and application," Food Feed Res., vol. 42, no. 1, pp. 11-22, 2015.

[14] A. Valdés, N. Burgos, A. Jiménez, and M. C. Garrigós, "Natural Pectin Polysaccharides as 
Edible Coatings," Coatings, vol. 5, no. 4, pp. 865-886, 2015.

[15] K. Prihatman, "Tanaman Buah Kedondong: Pos Pelayanan Informasi Masyarakat UKM," 2004. .

[16] M. K. Manik, "Study of Antimicrobial, Antioxidant and Thrombolytic activity of the fruit skin of Spondias pinnata," East West University, 2012.

[17] J. H. Crane and J. Wasielewski, "Spondias Growing in the Florida Home Landscape 1," Florida, 2015.

[18] G. Phillips and P. Williams, Hand Book of Hydrocolloids, 2nd ed. OX: Woodhead Publishing, 2009.

[19] B. Hastuti, "Pektin dan Modifikasinya untuk Meningkatkan Karakteristik sebagai Adsorben," in Prosiding Seminar Nasional Kimia dan Pendidikan Kimia VIII, 2016, pp. $157-169$.

[20] B. Yousuf, O. S. Qadri, and A. K. Srivastava, "Recent developments in shelf-life extension of fresh-cut fruits and vegetables by application of different edible coatings: A review," LWT - Food Sci. Technol., vol. 89, no. 3, pp. 198-209, 2017.

[21] S. Galus and J. Kadzińska, "Food applications of emulsion-based edible films and coatings," Trends Food Sci. Technol., vol. 45, no. 2, pp. 273-283, 2015.

[22] G. I. Olivas and D. S. Mattinson, "Alginate coatings for preservation of minimally processed ' Gala' apples," Postharvest Biol. Technol., vol. 45, no. 1, pp. 89-96, 2007.

[23] M. E. Martiñon, R. G. Moreira, M. E. Castell-perez, and C. Gomes, "Development of a multilayered antimicrobial edible coating for shelf- life extension of fresh-cut cantaloupe (Cucumis melo L.) stored at 4 C," LWT - Food Sci. Technol., vol. 56, no. 2, pp. 341-350, 2014.

[24] J. Correa-betanzo, J. K. Jacob, C. Perez-perez, and G. Paliyath, "Effect of a sodium caseinate edible coating on berry cactus fruit (Myrtillocactus geometrizans ) phytochemicals," Food Res. Int., vol. 44, no. 7, pp. 1897-1904, 2011.

[25] I. G. Moorthy, J. P. Maran, S. Ilakya, S. L. Anitha, S. P. Sabarima, and B. Priya, "Ultrasound Assisted Extraction of Pectin From waste artocarpus heterophyllus Fruit Peel," Ultrason. - Sonochemistry, vol. 34, no. 1, pp. 525-530, 2016.

[26] B. R. Sharma, L. Naresh, N. C. Dhuldhoya, S. U. Merchant, and U. C. Merchant, "An Overview on Pectins," Times Food Process. J., vol. 51, no. 2, pp. 44-51, 2006.

[27] J. Fu and M. A. Rao, "Rheology and structure development during gelation of lowmethoxyl pectin gels : the effect of sucrose," Food Hydro, vol. 15, no. 1, pp. 93-100, 2001.

[28] A. Strom, P. Ribelles, L. Lundin, I. Norton, E. R. Morris, and M. A. K. Williams, "Influence of Pectin Fine Structure on the Mechanical Properties of Calcium - Pectin and Acid - Pectin Gels," Biomacromolecules, vol. 8, no. 9, pp. 2668-2674, 2007.

[29] S. Y. Chan, W. S. Choo, D. J. Young, and X. J. Loh, "Pectin as a Rheology Modifier: Origin, Structure, Commercial Production and Rheology," Carbohydr. Polym., vol. 161, no. 1, pp. 118-139, 2016.

[30] S. Chan and W. Choo, "Effect of extraction conditions on the yield and chemical properties of pectin from cocoa husks," Food Chem., vol. 141, no. 4, pp. 3752-3758, 2013.

[31] A. K. Tiwari, S. N. Saha, and V. P. Yadav, "Extraction and Characterization of Pectin from 
Orange Peels," Int. J. Biotechnol. Biochem., vol. 13, no. 1, pp. 39-47, 2017.

[32] T. Lin, T. Feng, Y. Chung, and C. Lan, "Quantification of methyl ester content of pectin by pectinesterase," Bot. Bull. Acad. Sin., vol. 31, pp. 273-278, 1990.

[33] U. Sotanaphun, A. Chaidedgumjorn, N. Kitcharoen, M. Satiraphan, P. Asavapichayont, and P. Sriamornsak, "Preparation of Pectin from Fruit Peel of Citrus maxima," Silpakorn Univ. Sci. Technol. J., vol. 6, no. 1, pp. 42-48, 2012.

[34] P. H. F. Pereiraa et al., "Pectin extraction from pomegranate peels with citric acid," Int. J. Biol. Macromol., vol. 88, no. 1, pp. 373-379, 2016.

[35] A. Dhanapal, P. Sasikala, L. Rajamani, V. Kavitha, G. Yazhini, and M. S. Banu, "Edible films from Polysaccharides," Food Sci. Qual. Manag., vol. 3, no. 1, pp. 9-18, 2012.

[36] H. J. Kang, C. Jo, J. Kwon, H. Chung, and M. Byun, "Effect of a pectin-based edible coating containing green tea powder on the quality of irradiated pork patty," Food Control, vol. 18, no. 5, pp. 430-435, 2007.

[37] P. E. Susilowati, A. Fitri, and M. Natsir, "Penggunaan Pektin Kulit Buah Kakao sebagai Edible Coating pada Kualitas Buah Tomat dan Masa Simpan," J. Apl. Teknol. Pangan, vol. 6, no. 2, pp. 1-4, 2017.

[38] M. Moalemiyan, H. S. Ramaswamy, and N. Maftoonazad, "Pectin-based edible coating for shelf-life extension of ataulfo mango," J. Food Process Eng., vol. 35, no. 4, pp. 1-29, 2011.

[39] K. Ulfah, "Perlakuan blansir dan edible coating dari pektin untuk mereduksi senyawa akrilamida pada proses penggorengan keripik pisang ambon," 2012. 